\title{
Fe(II)-Based GDE Electrodes for the Demineralization of Methylene Blue Dye
}

\author{
S. Z. J. Zaidi ${ }^{1}$ - E. Hurter ${ }^{1}$ - F. C. Walsh ${ }^{1}$ - C. Ponce de León ${ }^{1}$ \\ Received: 8 November 2018 / Accepted: 13 March 2019 / Published online: 5 April 2019 \\ (c) The Author(s) 2019, corrected publication 2019
}

\begin{abstract}
This paper describes the removal of methylene blue (MB) dye using [Fe(II)]-based gas diffusion electrodes (GDEs). GDEs were developed by rolling carbon black and polytetrafluoroethylene as a conductive layer for efficient oxygen reduction reaction, with an $[\mathrm{Fe}(\mathrm{II})]$ ink layer $\left(5 \mathrm{mg} \mathrm{cm}^{-2}\right.$ loading) to conduct Fenton chemistry. The GDEs demonstrated the ability to remove the colour and mineralize MB dye in an undivided, three-electrode cell. Colour removal achieved $99 \%$ in a $150 \mathrm{~cm}^{3}$ solution containing $100 \mathrm{ppm}$ of $\mathrm{MB}$ dye at constant potential of $-1.0 \mathrm{~V}$ vs. $\mathrm{Hg} / \mathrm{HgSO}_{4}$ in $240 \mathrm{~min}$. The kinetics of the MB decolouration showed pseudo-first-order batch kinetics. The results demonstrated that a GDE containing immobilized Fe(II) ions appears to be a viable option for the environmental remediation of organic dyes in wastewater by an anodic Fenton oxidation.
\end{abstract}

Keywords Demineralization $\cdot$ Electro-Fenton $\cdot \mathrm{Fe}(\mathrm{II}) \cdot$ Gas diffusion electrodes $\cdot$ Methylene blue dye

\section{Introduction}

Across the world, one in nine people do not have access to clean water [1]. Possibly aggravated by climate change, population growth has led to water shortages that could adversely affect many major cities across the globe. Efficient water usage and minimizing water pollution are hence of the utmost importance [2].

Sectors of chemical water treatment have looked at the practical use of hydrogen peroxide for water purification and chemical mineralization. It is the simplest peroxide and a very weak acid, but a much stronger oxidizing agent than water [3]. It is also well known that hydrogen peroxide naturally decomposes to water and oxygen, and is there-

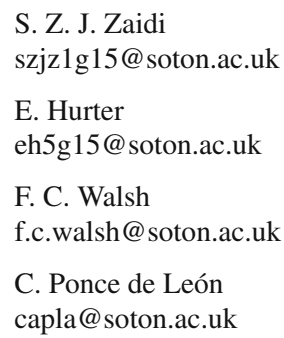

1 Electrochemical Engineering Laboratory, Faculty of Engineering and Environment, Engineering Sciences, University of Southampton, Highfield, Southampton SO17 1BJ, UK fore environmental friendly. Among other uses, it is widely used as a bleaching and sterilization agent in the pulp and paper manufacture - the biggest application of industrially produced hydrogen peroxide [4].

Currently, hydrogen peroxide can be produced by using many synthesis techniques including electro-Fenton [5], photo electro-Fenton [6], and solar electro-Fenton [7]. These technologies produce hydrogen peroxide in situ and thus negate the hazards and costs of handling and transporting bulk hydrogen peroxide. However, all these methods have limitations related to high material and catalyst costs. There is a clear need to develop new electrodes that may provide efficient catalysis for low-cost wastewater treatment. Carbon-based materials proved to be an acceptable cathode option for the reduction of oxygen to $\mathrm{H}_{2} \mathrm{O}_{2}$ and are the prime choice as an electrocatalyst because of their large surface area, chemical stability, and inexpensive cost. Moderate-cost carbon-based material electrodes have been designed for anodic water treatment, such as reticulated vitreous carbon (RVC) by electrodepositing titanate nanosheets (TINS) over the surface for electrochemical water treatment [8]. $\mathrm{PbO}_{2}$ electrodes have also been shown potential as an improved catalyst for mineralization of wastewater [9]. Similarly, a GDE may be considered as a cheap alternative to perform electro-Fenton water treatment. It has been shown that using butylanthraquinone improves the GDE's perfor- 
mance, showing a Faradic efficiency of about $90 \%$ for $\mathrm{H}_{2} \mathrm{O}_{2}$ production [10]. Nitrogen-functionalized carbon nanotube (NCNT) electrodes were found to be effective for the complete removal of methyl orange at an applied potential of $-0.85 \mathrm{~V}$ vs. SCE in $60 \mathrm{~min}$ [11]. There has however been no research work that studied the effect of electrode synthesis with $\mathrm{Fe}$ (II) salt over the electrode surface. In this work, novel GDE electrodes were prepared by rolling carbon black over a metal current collector, with a layer of $\mathrm{Fe}(\mathrm{II})$ chloride salt introduced onto the GDE for the mineralization of methylene blue.

\section{Experimental Details}

Carbon cloth (EC-AC-Cloth-T) was obtained from fuel cell, USA; Carbon black VULCAN ${ }^{\circledR}$ XC72R from Cabot; and reagent grade nickel mesh was obtained from Dexmet corporation, USA. Polytetrafluoroethylene (DuPont ${ }^{\mathrm{TM}}$ Teflon $^{\circledR}$ PTFE DISP 30) was used as a binder. Reagent grade sodium sulphate, acetone, methylene blue, potassium permanganate were obtained from Fischer scientific and used as received.

\subsection{Gas Diffusion Electrodes}

The improved gas diffusion cathode (GDE) consisted of a conductive catalytic carbon layer and a $\mathrm{Ni}$ mesh as current collector. An ink for catalyst layer was made with $125 \mathrm{mg}$ iron (II) chloride and $25 \mathrm{mg}$ of carbon. The mixture was sonicated with a Grant ultrasonic bath (XUBA3) for $15 \mathrm{~min}$ in a $5 \mathrm{wt} \% \mathrm{Nafion}^{\circledR}$ aliphatic alcohol suspension (D-520 dispersion, Alfa Aesar) with a weight ratio of 3:2 for (catalysts + carbon)/Nafion, providing a $5 \mathrm{mg} \mathrm{cm}^{2}$ iron loading. Conductive carbon ink was layered on $50 \mathrm{~mm} \times$ $50 \mathrm{~mm} \times 0.11 \mathrm{~mm}$ piece of $25 \mathrm{wt} \%$ PTFE-treated carbon cloth.

Finally, the current collector, a $0.05 \mathrm{~mm}$-thick nickel mesh, was placed on top of the layered carbon cloth with $\mathrm{Fe}(\mathrm{II})$ layer and the electrode was hot-pressed for $2 \mathrm{~min}$ at $140{ }^{\circ} \mathrm{C}$ and $5 \mathrm{MPa}$.

\subsection{Electrochemical Experiments and Analysis Procedures}

The electrochemical studies were conducted by using computer-aided PGSTAT302 N potentiostat/galvanostat from Autolab (EcoChemie, Netherlands) by means of Nova 1.11 software. The prepared GDE with iron loading was used as a working electrode (active electrode area $0.79 \mathrm{~cm}^{2}$ ); $\mathrm{Hg} / \mathrm{HgSO}_{4}$ and $\mathrm{Pt}$ mesh were employed as a reference and a counter electrode, respectively. A solution of $150 \mathrm{~cm}^{3}$ of $100 \mathrm{ppm}$ of MB dye in $0.05 \mathrm{moldm}^{-3}$ of sodium sul- phate (background electrolyte) was electrolysed at $-0.7 \mathrm{~V}$, -0.8 , and $-1.0 \mathrm{~V}$ vs. $\mathrm{Hg} / \mathrm{Hg}_{2} \mathrm{SO}_{4}$ in an undivided electrochemical cell by feeding pure oxygen gas at a flowrate of $0.15 \mathrm{~L} \mathrm{~min}^{-1}$

The absorbance of the MB dye in solution was measured in a Hitachi U3010 UV-Vis spectrophotometer at a wavelength of $664 \mathrm{~nm}$. A linear calibration curve obeying the BeerLambert law was employed to calculate the concentration of MB from the solution after colour removal. Shimadzu TOC$\mathrm{V}_{\mathrm{CPH}}$ TOC analyser was used for mineralization studies of the MB dye. Reproducible TOC values were determined by injecting $100 \mu \mathrm{dm}^{-3}$ aliquots into the TOC analyser by employing the standard non-purgeable organic carbon method.

\section{Results and Discussion}

\subsection{The Optimal Cathode Potential Using a GDE}

The dissolved oxygen is electrochemically converted into $\mathrm{H}_{2} \mathrm{O}_{2}$ at the carbon surface of the cathode via the oxygen reduction reaction (ORR). However, it has also been reported that in this process, two further 'side' reactions compete with the ORR [12]. These two side reactions are the further reduction of $\mathrm{H}_{2} \mathrm{O}_{2}$ to $\mathrm{H}_{2} \mathrm{O}$, and hydrogen gas evolution:

$\mathrm{O}_{2}+2 \mathrm{H}^{+}+2 \mathrm{e}^{-} \rightarrow \mathrm{H}_{2} \mathrm{O}_{2} \quad E^{\circ}=0.695 \mathrm{~V}$ vs. SHE

$\mathrm{H}_{2} \mathrm{O}_{2}+2 \mathrm{H}^{+}+2 \mathrm{e}^{-} \rightarrow 2 \mathrm{H}_{2} \mathrm{O} \quad E^{\circ}=1.763 \mathrm{~V}$ vs. SHE

$2 \mathrm{H}^{+}+2 \mathrm{e}^{-} \rightarrow \mathrm{H}_{2}(\mathrm{~g}) \quad E^{\circ}=0.00 \mathrm{~V}$ vs. SHE

The reactions can be seen when the polarization curves are achieved using the GDE as the cathode. Figure 1 shows the current rise when the potential is applied. Results indicated that an oxygen reduction wave takes place in the range of -0.3 to $-0.9 \mathrm{~V}$ vs. $\mathrm{Hg} / \mathrm{HgSO}_{4}$. This current region represents the maximum rate of oxygen reduction to $\mathrm{H}_{2} \mathrm{O}_{2}$.

When the applied potential continues to decrease below $-1 . \mathrm{O} \mathrm{V}$ vs. $\mathrm{Hg} / \mathrm{HgSO}_{4}$, the current density increases sharply. This region indicates the occurrence of the two side reactions, which were mentioned in Eqs. (2) and (3).

\subsection{Demineralization of MB by Using Fe-Based GDE Electrodes}

The demineralization of MB dye was studied by constant potential electrolysis in the region of oxygen reduction as seen in the polarization curve studies (see Fig. 1). Three potentials $\left(-0.7,-0.8\right.$, and $-1.0 \mathrm{~V}$ vs. $\left.\mathrm{Hg} / \mathrm{HgSO}_{4}\right)$ were selected for electro-Fenton degradation of MB dye. The 


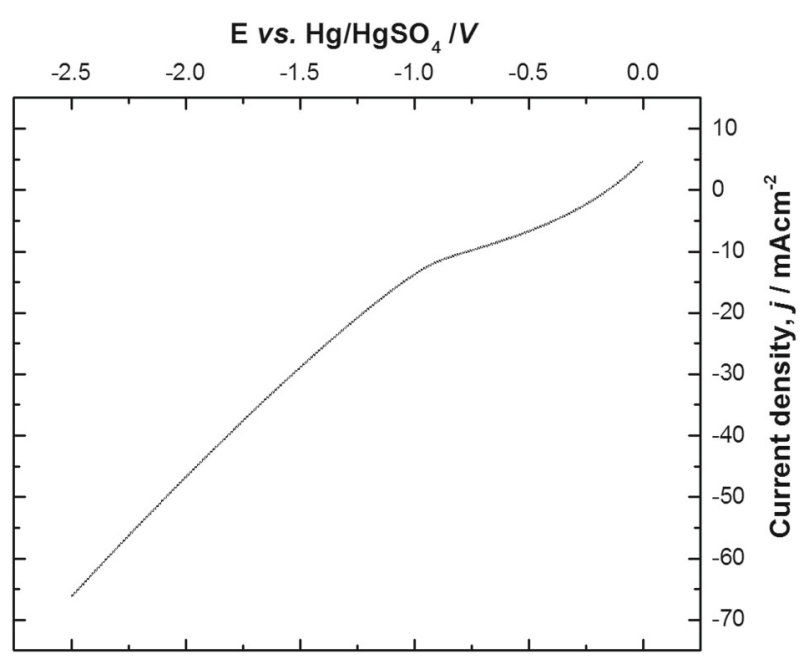

Fig. 1 Polarization curve at GDE electrodes without $\mathrm{Fe}(\mathrm{II})$ ion for the determination of ORR in an electrolyte containing in $0.05 \mathrm{~mol} \mathrm{dm}^{-3} \mathrm{Na}_{2} \mathrm{SO}_{4}$ potential sweep rate $=10 \mathrm{mV} \mathrm{s}^{-1}$; temperature: $25^{\circ} \mathrm{C}$

demineralization and colour removal of the MB dye were enhanced by ${ }^{\bullet} \mathrm{OH}$ radical formation through the decomposition of electro-generated $\mathrm{H}_{2} \mathrm{O}_{2}$ in the presence of $\mathrm{Fe}^{2+}$ ions at the surface of the $\mathrm{Fe}$ (II)-based GDE electrodes. The mechanism for the generation of ${ }^{\bullet} \mathrm{OH}$ radical at the $\mathrm{Fe}$ (II)-based GDE electrodes [3] is given as follows:

$$
\mathrm{H}_{2} \mathrm{O}_{2}+\mathrm{Fe}^{2+}+\mathrm{H}^{+} \rightarrow \cdot \bullet \mathrm{OH}+\mathrm{Fe}^{3+}+\mathrm{H}_{2} \mathrm{O}
$$

$150 \mathrm{~cm}^{3}$ of electrolyte containing $100 \mathrm{ppm}$ of $\mathrm{MB}$ dye and $0.05 \mathrm{~mol} \mathrm{dm}^{-3}$ of $\mathrm{Na}_{2} \mathrm{SO}_{4}$ at $\mathrm{pH} 3$ was employed for electrolysis studies with working electrode (GDE with $\mathrm{Fe}(\mathrm{II})$ ), counter electrode (platinum), and reference electrode $\left(\mathrm{Hg} / \mathrm{HgSO}_{4}\right)$. During the electro-Fenton electrolysis studies, samples $\left(2 \mathrm{~cm}^{3}\right)$ were withdrawn at regular intervals (5 min).

It can be seen from the results of $\mathrm{MB}$ dye demineralization at potential of $-0.7 \mathrm{~V} \mathrm{vs} . \mathrm{Hg} / \mathrm{HgSO}_{4}$ that the intensity of the visible light band dropped continuously until $92 \%$ of discoloration of the solution was achieved after $240 \mathrm{~min}$, as shown in Fig. 2. The colour removal and demineralization of MB dye can result in the generation of aromatic and aliphatic intermediates, which ultimately degrade to basic inorganic $\mathrm{CO}_{2}$ molecules. The time vs. normalized concentration plot of MB dye at different constant potentials electrolysis $(-0.7$, -0.8 , and $-1.0 \mathrm{~V}$ vs. $\mathrm{Hg} / \mathrm{HgSO}_{4}$ ) can be seen in Fig. 2. It is interesting to note that by increasing the potential of -1.0 $\mathrm{V}$ vs. $\mathrm{Hg} / \mathrm{HgSO}_{4}$, the overall discoloration was about $99 \%$ in 240 minutes.

Pseudo-first-order reaction kinetics, quantifying the rate of dye degradation, were calculated via:

$\ln \left(\frac{c}{c_{0}}\right)=-k t$

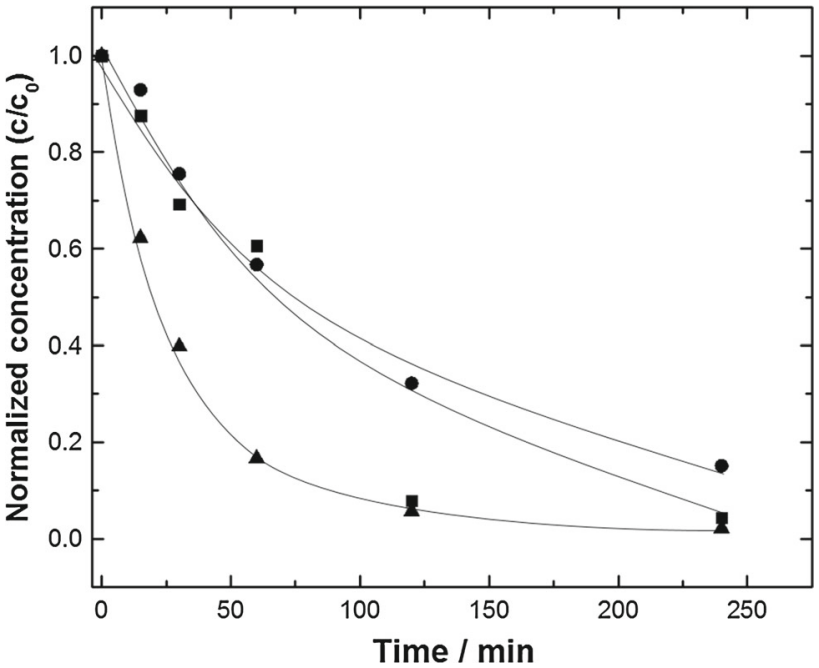

Fig. 2 Electrochemical remediation of MB dye by using Fe(II)-based GDE • $)-0.7 \mathrm{~V}$ vs. $\mathrm{Hg} / \mathrm{HgSO}_{4}$ 口) $-0.8 \mathrm{~V}$ vs. $\left.\mathrm{Hg} / \mathrm{HgSO}_{4} \boldsymbol{\Delta}\right)-1.0 \mathrm{~V}$ vs. $\mathrm{Hg} / \mathrm{HgSO}_{4}$

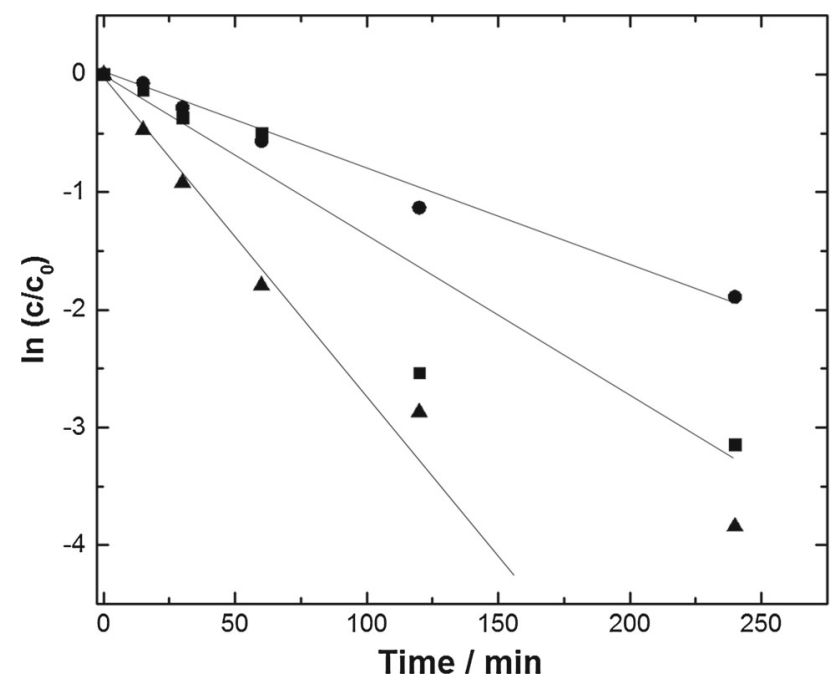

Fig. 3 Electrochemical remediation kinetics of $\mathrm{MB}$ dye using $\mathrm{Fe}(\mathrm{II})$ based $\mathrm{GDE} \bullet)-0.7 \mathrm{~V}$ vs. $\mathrm{Hg} / \mathrm{HgSO}_{4}$, 口) $-0.8 \mathrm{~V}$ vs. $\mathrm{Hg} / \mathrm{HgSO}_{4}, \boldsymbol{\Delta}$ ) $-1.0 \mathrm{~V}$ vs. $\mathrm{Hg} / \mathrm{HgSO}_{4}$

where $k$ is the apparent first-order rate constant for the batch decay, $c$ is the final concentration, $c_{\mathrm{O}}$ is an initial concentration, and $t$ is the time.

The pseudo rate constant $k=-0.0158 \mathrm{~min}^{-1}$ with linear pseudo-first-order degradation was calculated from Eq. (5) at a potential of $-1.0 \mathrm{~V}$ vs. $\mathrm{Hg} / \mathrm{HgSO}_{4}{ }^{\prime}$; rate constant values at other potentials are shown in Fig. 3.

The total organic carbon (TOC) decay obtained for MB degradation implied that TOC dropped from 50 to $17 \mathrm{mg}$ $\mathrm{dm}^{-3}$ by applying a constant potential of $-1.0 \mathrm{~V}$ vs. $\mathrm{Hg} / \mathrm{HgSO}_{4}$, as shown in Fig. 4.

The degradation pathway is shown in Fig. 5 [13]. The proposed degradation pathway involves an initial central 
aromatic heterocycle bond breaking for both sulphur and nitrogen by the addition of ${ }^{\bullet} \mathrm{OH}$ radical. Further, central atomic ring rupture by ${ }^{\bullet} \mathrm{OH}$ radical will likely lead to the generation of transitional intermediates. The intermediates species of MB dye converted into amino benzene sulphonic acid as a principal specie by ${ }^{\bullet} \mathrm{OH}$ radical. The addition of - $\mathrm{OH}$ radicals further eliminates $\mathrm{NH}_{2}$ and $\mathrm{SO}_{2}$ group from amino benzene sulphonic acid and converted this principal specie of MB dye to benzene sulphonic acid and phenol. Finally, MB dye containing aromatic rings is ruptured and readily converted to aliphatic acids, carbon dioxide, and water [14].

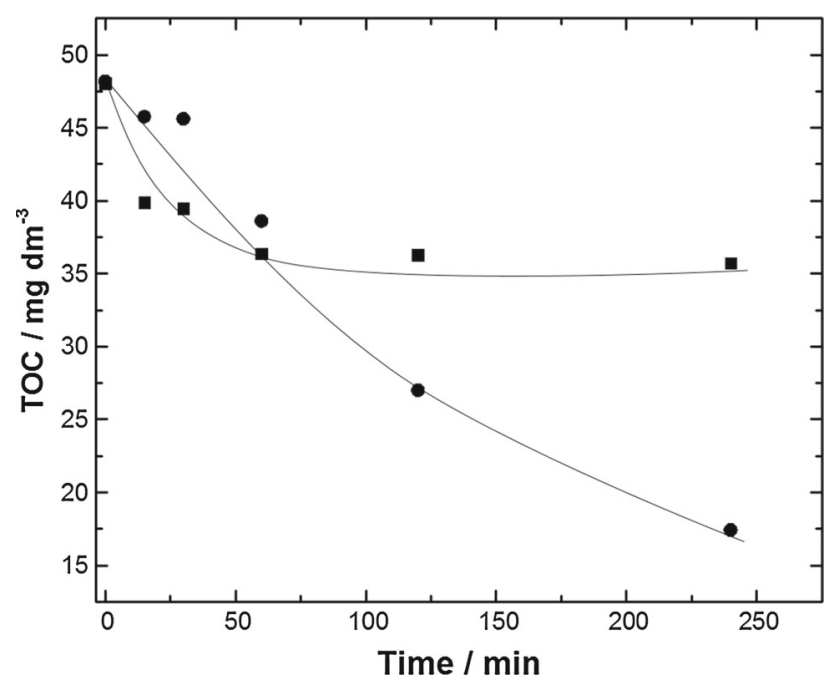

Fig. 4 Effect of different potentials on TOC abatement vs. electrolysis time by using $\mathrm{Fe}$ (II) based GDE in $100 \mathrm{ppm}$ of MB dye and $0.05 \mathrm{moldm}^{-3} \mathrm{Na}_{2} \mathrm{SO}_{4}$ as a background electrolyte $-0.1 \mathrm{~V}$ vs. $\mathrm{Hg} / \mathrm{HgSO}_{4}$, $\mathbf{\square}-1.0 \mathrm{~V}$ vs. $\mathrm{Hg} / \mathrm{HgSO}_{4}$
The TOC removal efficiency was found to be $66 \%$ at $-1.0 \mathrm{~V}$ vs. $\mathrm{Hg} / \mathrm{HgSO}_{4}$ in $30 \mathrm{~min}$ of electrochemical treatment. However, lower TOC decay was observed while electrolysing MB solutions at less negative potentials $(-0.7$ $\mathrm{V}$ vs. $\mathrm{Hg} / \mathrm{HgSO}_{4}$ ). This implies that the use of more negative constant potential $\left(-1.0 \mathrm{~V}\right.$ vs. $\left.\mathrm{Hg} / \mathrm{HgSO}_{4}\right)$ is more effective for the mineralization as shown in Fig. 6, which denotes mineralization efficiency. Ren et al. [15] investigated the mineralization of tartrazine by using electro-Fenton process by applying $4 \mathrm{~V}$ cell voltage. At $\mathrm{pH} 3$, the mineralization removal efficiency of $64 \%$ was achieved in a vertical flow reactor in $180 \mathrm{~min}$ of electrolysis.

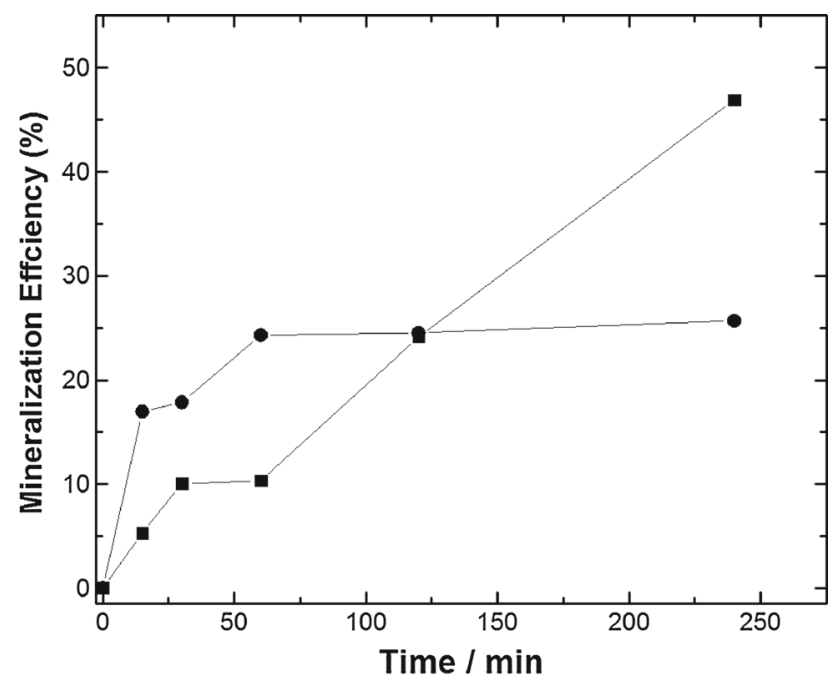

Fig. 6 Mineralization efficiency vs. electrolysis time by using $\mathrm{Fe}(\mathrm{II})$ based GDE in $100 \mathrm{ppm}$ of $\mathrm{MB}$ dye and $0.05 \mathrm{moldm}^{-3} \mathrm{Na}_{2} \mathrm{SO}_{4}$ as a background electrolyte -) $-0.7 \mathrm{~V}$ vs. $\mathrm{Hg} / \mathrm{HgSO}_{4}$, 口) $-1.0 \mathrm{~V}$ vs. $\mathrm{Hg} / \mathrm{HgSO}_{4}$
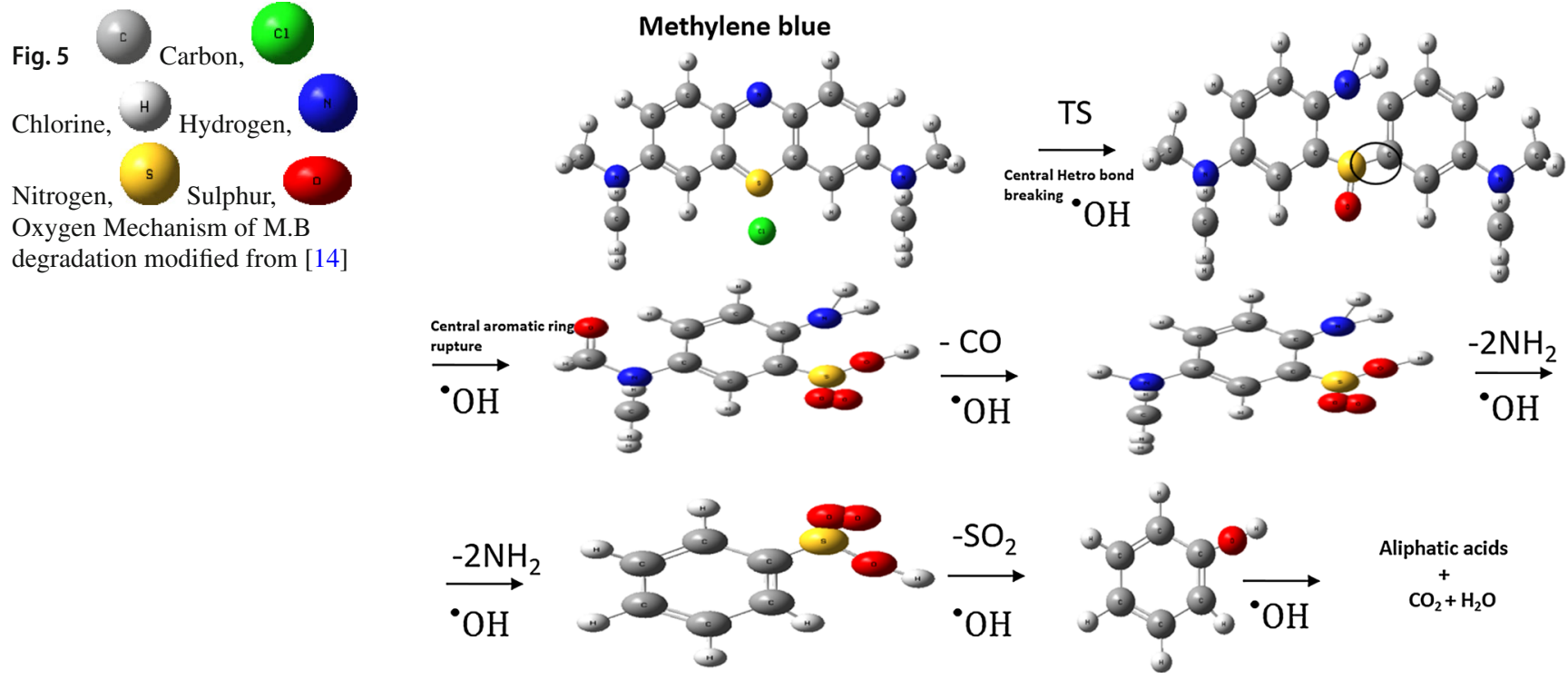


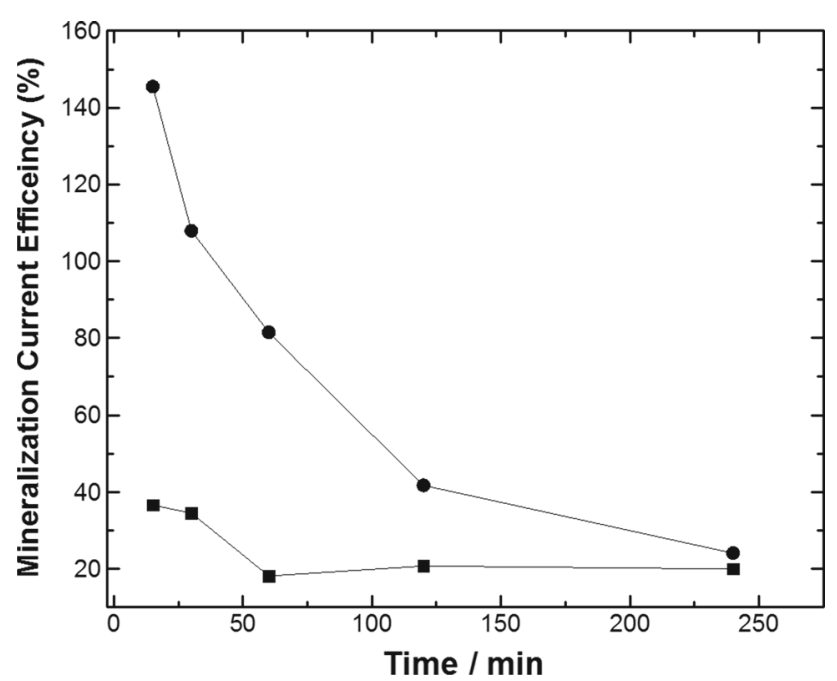

Fig. 7 Mineralization current efficiency calculated from Eq. (6) vs. electrolysis time by using Fe(II) based GDE in $100 \mathrm{ppm}$ of MB dye and $0.05 \mathrm{~mol} \mathrm{dm}^{-3} \mathrm{Na}_{2} \mathrm{SO}_{4}$ as a background electrolyte $-0.7 \mathrm{~V}$ vs. $\mathrm{Hg} / \mathrm{HgSO}_{4}$, $)-1.0 \mathrm{~V}$ vs. $\mathrm{Hg} / \mathrm{HgSO}_{4}$

TOC results for the mineralization of MB dye obtained in this article were improved in comparison with the reported values present in the literature [15] which employed related technologies.

\subsection{Current Efficiency and Energy Consumption}

Current efficiency is defined as the ratio of electricity consumed for electrochemical demineralization reaction to overall charge passed through the electrochemical process. The current efficiency $(\phi)$ values for the electrochemical process are calculated from the expression [16];

$$
\varnothing=\frac{2.67\left[\mathrm{TOC}_{0}-\mathrm{TOC}_{\mathrm{f}}\right] \mathrm{FV}}{\mathbf{8} \int_{0}^{t} I \mathrm{~d} t \mathrm{t}} \times 100
$$

where 2.67 is the reported conversion factor of $\mathrm{COD}$ (chemical oxygen demand) to TOC, $\left(\mathrm{TOC}_{0}\right)$ and $\left(\mathrm{TOC}_{\mathrm{f}}\right)$ related to the TOC $\left(\mathrm{g} \mathrm{dm}^{-3}\right)$ values at initial and final time of electrolysis respectively, $F$ is the Faraday constant $\left(96,485 \mathrm{C} \mathrm{mol}^{-1}\right), V$ is the volume of electrolyte $\left(\mathrm{dm}^{3}\right), 8$ is the factor for oxygen equivalent mass $\left(\mathrm{g} \mathrm{eq}^{-1}\right), \int_{0}^{t} I \mathrm{~d} t$ overall charge passed during the time interval in an electrochemical reaction, and $t$ is related to the overall time interval (s) of electrolysis process.

This parameter is dependent upon TOC reduction values, electrolysis time, and overall charge passed. The mineralization current efficiency (MCE) is shown in Fig. 7 against time of electrolysis.

The MCE value is found to be more efficient at lower applied potentials. As can be seen at $-0.7 \mathrm{~V}$ vs. $\mathrm{Hg} / \mathrm{HgSO}_{4}$, the efficiency achieved after $30 \mathrm{~min}$ of electrolysis was approximately $100 \%$ (due to generation of ${ }^{\bullet} \mathrm{OH}$ radicals and decomposition of complex structure of RB- 5 dye) and gradually decreased with time to final value of $24 \%$ [calculated from Eq. (6)]. Thiam et al. reported the mineralization of acid red 14 dye by using air diffusion electrodes and electroFenton technology.

At operating conditions (Table 1), mineralization current efficiency of only $10 \%$ was obtained during electrolysis of AR 14 dye by applying current density of $100 \mathrm{~mA} \mathrm{~cm}^{-2}$ [17]. However, by applying higher potential $(-1.0 \mathrm{~V}$ vs. $\mathrm{Hg} / \mathrm{HgSO}_{4}$ ) in this study, the highest current efficiency achieved was about $31 \%$ at the end of electrolysis. Initially, greater values of MCE at the beginning is due to the fact that enormous amounts of aromatic groups are dissociated into

Table 1 The comparison of energy consumption and removal efficiency of this study with literature

\begin{tabular}{|c|c|c|c|c|c|}
\hline Method & Optimum conditions & $\begin{array}{l}\text { Energy } \\
\text { consumption } \\
\left(\mathrm{kWh} \mathrm{kg}^{-1} \text { TOC) }\right.\end{array}$ & $\begin{array}{l}\text { Removal } \\
\text { efficiency } / \%\end{array}$ & Time/min or $\mathrm{h}$ & Reference \\
\hline Electro-Fenton & $\begin{array}{l}\text { Iron } 0.4 \times 10^{-3} \mathrm{~mol} \mathrm{dm}^{-3} \\
0.05 \mathrm{~mol} \mathrm{dm}^{-3} \mathrm{Na}_{2} \mathrm{SO}_{4} \\
\mathrm{pH}=3, E_{\text {cell }}=1.4 \mathrm{~V}\end{array}$ & 350 & 65 & $180 \mathrm{~min}$ & {$[15]$} \\
\hline Electro-Fenton & $\begin{array}{l}\text { Iron } 0.5 \times 10^{-3} \mathrm{~mol} \mathrm{dm}^{-3} \\
0.05 \mathrm{~mol} \mathrm{dm}^{-3} \mathrm{Na}_{2} \mathrm{SO}_{4} \\
40^{\circ} \mathrm{C}, \mathrm{pH}=3 \\
j=100 \mathrm{~mA} \mathrm{~cm} \\
\end{array}$ & 1280 & 76 & $480 \mathrm{~min}$ & {$[17]$} \\
\hline Electro-Fenton & $\begin{array}{l}\text { Iron } 0.1 \times 10^{-3} \mathrm{~mol} \mathrm{dm}^{-3} \\
0.05 \mathrm{~mol} \mathrm{dm}^{-3} \mathrm{Na}_{2} \mathrm{SO}_{4} \\
40^{\circ} \mathrm{C}, \mathrm{pH}=3 \\
I=120 \mathrm{~mA}\end{array}$ & 500 & 100 & $240 \mathrm{~min}$ & {$[18]$} \\
\hline $\begin{array}{l}\text { GDE with } \\
\text { immobilized iron } \\
\text { ions }\end{array}$ & $\begin{array}{l}\text { GDE, Iron } 125 \mathrm{mg}, \\
0.05 \mathrm{~mol} \mathrm{dm}^{-3} \mathrm{Na}_{2} \mathrm{SO}_{4}, \\
\boldsymbol{E}=-1.0 \mathrm{~V} \text { vs. } \mathrm{Hg} / \mathrm{HgO}, \\
\mathrm{pH}=3, T=25^{\circ} \mathrm{C}\end{array}$ & 147 & 66 & $30 \mathrm{~min}$ & This study \\
\hline
\end{tabular}




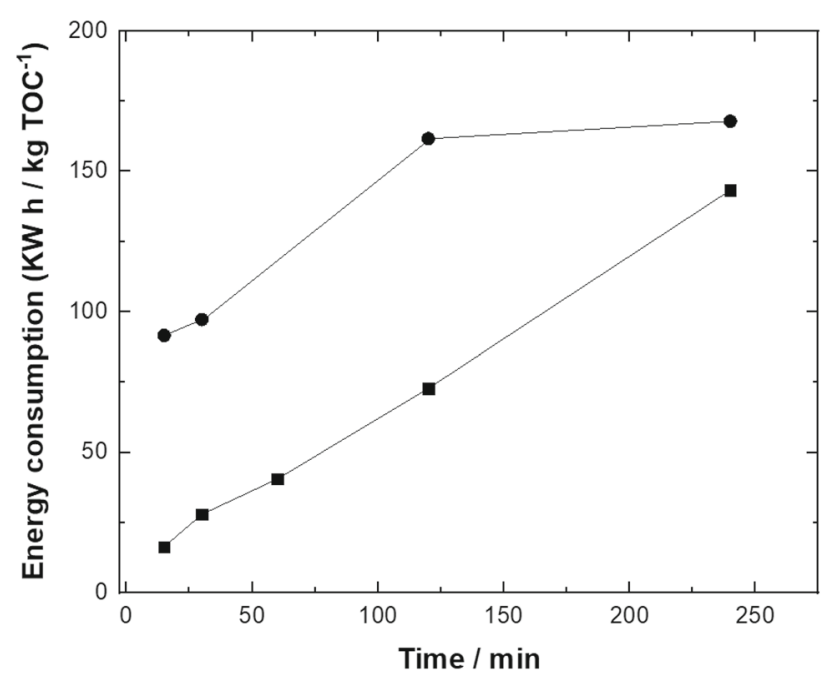

Fig. 8 Energy consumption calculated from Eq. (7) vs. electrolysis time by using $\mathrm{Fe}$ (II) based GDE in $100 \mathrm{ppm}$ of MB dye and $0.05 \mathrm{~mol} \mathrm{dm}^{-3} \mathrm{Na}_{2} \mathrm{SO}_{4}$ as a background electrolyte $-1.0 \mathrm{~V}$ vs. $\mathrm{Hg} / \mathrm{HgSO}_{4}$, 口) $-0.7 \mathrm{~V}$ vs. $\mathrm{Hg} / \mathrm{HgSO}_{4}$

inorganic degradable products and gradually transformed into $\mathrm{CO}_{2}$, whereas after a prolonged time interval during electrolysis, the decrease in MCE was due to difficult degradation of organic compounds to inorganic carbon dioxide. However, at higher potential, the occurrence of side reactions may cause a decrease in current efficiency.

The energy consumption, EC, ( $\left.\mathrm{kWh} \mathrm{kg}^{-1} \mathrm{TOC}\right)$ was evaluated following equation [5];

$\mathrm{EC}=\frac{E I_{\mathrm{o}} \Delta t}{100\left(\mathrm{TOC}_{0}-\mathrm{TOC}_{\mathrm{f}}\right) V}$

where $E(\mathrm{~V})$ is the applied potential, $I_{\mathrm{O}}(\mathrm{A})$ is the current passed during electrochemical reaction, $\Delta t(\mathrm{~h})$ the electrolysis time, $\left(\mathrm{TOC}_{0}\right)$ and $\left(\mathrm{TOC}_{\mathrm{f}}\right)$ related to the $\mathrm{TOC}$ $\left(\mathrm{kg} \mathrm{dm}^{-3}\right)$ values at initial and final time of electrolysis, respectively, and $V\left(\mathrm{dm}^{3}\right)$ corresponds the electrolyte volume.

Like MCE, energy consumption rises as expected, since it takes higher energy to convert mixed organic compounds formed from broken down products of MB. After $250 \mathrm{~min}$, the energy consumption was about $147 \mathrm{kWh} \mathrm{kg}^{-1} \mathrm{TOC}$ at applied potential of $-0.7 \mathrm{~V}$ vs. $\mathrm{Hg} / \mathrm{HgSO}_{4}$ as seen in Fig. 8 . Fenton process was investigated for the mineralization of amoxicillin using titanium oxide as an emerging material which showed that energy consumption under optimum conditions was found to be $500 \mathrm{kWh} \mathrm{kg}^{-1}$ TOC [18]. This denotes the effectiveness of GDE containing immobilized $\mathrm{Fe}(\mathrm{II})$ ions discussed in this study for the removal of MB dye at lower energy in comparison with other electrodes in the literature. Note that the energy consumption for MB mineralization increases as applied potential raised to $-1.0 \mathrm{~V}$ vs. $\mathrm{Hg} / \mathrm{HgSO}_{4}$, but this energy consumption was much lower than what reported by Oturan et al. [18].

\section{Conclusions}

It has been demonstrated that improved GDEs have been synthesized with a conductive layer of carbon black and $\mathrm{Fe}$ (II) salt for the mineralization MB dye. Fe(II)-based GDE can effectively degrade MB dye with $99 \%$ colour removal. The mineralization efficiency was about $47 \%$ at an applied potential of $-1.0 \mathrm{~V}$ vs. $\mathrm{Hg} / \mathrm{HgSO}_{4}$. The pseudo-first-order concentration drop showed linear trends for the mineralization of MB dye. The mineralization current efficiency was about $100 \%$ for 30 -min electrolysis at constant potential of $-0.7 \mathrm{~V}$ vs. $\mathrm{Hg} / \mathrm{HgSO}_{4}$, while the energy consumption was $147 \mathrm{kWh} \mathrm{kg}^{-1} \mathrm{TOC}$ at applied potential of $-0.7 \mathrm{~V}$ vs. $\mathrm{Hg} / \mathrm{HgSO}_{4}$. The results elaborated the usefulness of $\mathrm{Fe}(\mathrm{II})$ based GDE electrodes for the degradation of MB dye.

Open Access This article is distributed under the terms of the Creative Commons Attribution 4.0 International License (http://creativecomm ons.org/licenses/by/4.0/), which permits unrestricted use, distribution, and reproduction in any medium, provided you give appropriate credit to the original author(s) and the source, provide a link to the Creative Commons license, and indicate if changes were made.

\section{References}

1. Thewaterproject: 10 Ways clean water changes the world. The Water Project Organization (Online) (2015). https:// thewaterproject.org/why-water/10-ways-clean-water-changesthe-world. Accessed: 03 Mar 2018

2. Ziervogel, G.; New, M.; Archer van Garderen, E.; Midgley, G.; Taylor, A.; Hamann, R.; Stuart-Hill, S.; Myers, J.; Warburton, M.: Climate change impacts and adaptation in South Africa. Wiley Interdiscip. Rev. Clim. Change 5, 605-620 (2015)

3. Burrows, A.; Holman, J.; Parsons, A.; Pilling, G.; Price, G.: Chemistry: Introducing Inorganic, Organic and Physical Chemistry. Oxford University Press, Oxford (2017)

4. Ando, Y.; Tanaka, T.: Proposal for a new system for simultaneous production of hydrogen and hydrogen peroxide by water electrolysis. Int. J. Hydrog. Energy 29, 1349-1354 (2004)

5. Vasconcelos, V.M.; Ponce-de-León, C.; Nava, J.L.; Lanza, M.R.: Electrochemical degradation of RB-5 dye by anodic oxidation, electro-Fenton and by combining anodic oxidation-electro-Fenton in a filter-press flow cell. J. Electroanal. Chem. 765, 179-87 (2016)

6. Salazar, R.; Ureta-Zañartu, M.S.: Mineralization of triadimefon fungicide in water by electro-Fenton and photo electro-Fenton. Water Air Soil Pollut. 223, 4199-4207 (2012)

7. Salazar, R.; Garcia-Segura, S.; Ureta-Zañartu, M.S.; Brillas, E.: Degradation of disperse azo dyes from waters by solar photoelectro-Fenton. Electrochim. Acta 56, 6371-6379 (2011)

8. Zaidi, S.Z.J.; Harito, C.; Walsh, F.C.; Ponce de León, C.; Decolourisation of reactive black-5 at an RVC substrate decorated with $\mathrm{PbO}_{2} / \mathrm{TiO}_{2}$ nanosheets prepared by anodic electrodeposition. J. Solid State Electrochem. 22, 1-12 (2018)

9. An, H.; Cui, H.; Zhang, W.; Zhai, J.; Qian, Y.; Xie, X.; Li, Q.: Fabrication and electrochemical treatment application of a microstructured $\mathrm{TiO}_{2}-\mathrm{NTs} / \mathrm{Sb}-\mathrm{SnO}_{2} / \mathrm{PbO}_{2}$ anode in the degradation of C.I. Reactive Blue 194 (RB194). Chem. Eng. J. 209, 86-93 (2012) 
10. Valim, R.B.; Reis, R.M.; Castro, P.S.; Lima, A.S.; Rocha, R.S.; Bertotti, M.; Lanza, M.R.: Electrogeneration of hydrogen peroxide in gas diffusion electrodes modified with tert-butyl-anthraquinone on carbon black support. Carbon 61, 236-44 (2013)

11. Zhang, X.; Fu, J.; Zhang, Y.; Lei, L.: A nitrogen functionalized carbon nanotube cathode for highly efficient electrocatalytic generation of $\mathrm{H}_{2} \mathrm{O}_{2}$ in electro-Fenton system. Sep. Purif. Technol. 64, 116-23 (2008)

12. Ponce-de-León, C.; Pletcher, D.: Removal of formaldehyde from aqueous solutions via oxygen reduction using a reticulated vitreous carbon cathode cell. J. Appl. Electrochem. 25, 307-314 (1995)

13. Frisch, M.J.; Trucks, G.W.; Schlegel, H.B.; Scuseria, G.E.; Robb, M.A.; Cheeseman, J.R.; Scalmani, G.; Barone, V.; Mennucci, B.; Petersson, G.A.; Nakatsuji, H.: Gaussian 09, p. 6492. Gaussian, Inc., Wallingford (2009)

14. Yang, C.; Dong, W.; Cui, G.; Zhao, Y.; Shi, X.; Xia, X.; Wang, W.: Highly efficient photocatalytic degradation of methylene blue by P2ABSA-modified $\mathrm{TiO}_{2}$ nanocomposite due to the photosensitization synergetic effect of $\mathrm{TiO}_{2}$ and P2ABSA. RSC Adv. 7(38), 23699-23708 (2017)
15. Ren, G.B.; Zhou, M.H.; Liu, M.M.; Ma, L.; Yang, H.J.: A novel vertical-flow electro-Fenton reactor for organic wastewater treatment. Chem. Eng. J. 298, 55-67 (2016)

16. Steter, J.R.; Barros, W.R.; Lanza, M.R.; Motheo, A.J.: Electrochemical and sonoelectrochemical processes applied to amaranth dye degradation. Chemosphere 117, 200-207 (2014)

17. Thiam, A.; Sirés, I.; Garrido, J.A.; Rodríguez, R.M.; Brillas, E.: Effect of anions on electrochemical degradation of azo dye Carmoisine (Acid Red 14) using a BDD anode and air-diffusion cathode. Sep. Purif. Technol. 140, 43-52 (2015)

18. Oturan, N.; Soliu, O.; Raffy, S.; Oturan, M.A.: Sub-stoichiometric titanium oxide as a new anode material for electro-Fenton process: application to electrocatalytic destruction of antibiotic amoxicillin. Appl. Catal. B Environ. 217, 214-223 (2017) 